\title{
Localization of the Action of Cholera Toxin on Adenyl Cyclase in Mucosal Epithelial Cells of Rabbit Intestine
}

\author{
David K. Parkinson, Hans Ebel, Donald R. DiBona, and \\ GeofFrey W. G. Sharp \\ From the Departments of Medicine, Massachusetts General Hospital and the \\ Harvard Medical School, Boston, Massachusetts 02115
}

\begin{abstract}
A B S TRACT Brush borders and plasma membranes have been purified from mucosal epithelial cells of rabbit ileum under control conditions and after treatment for $3 \mathrm{hr}$ with cholera toxin in vivo. The activity of several enzymes in these preparations was measured. It was concluded that adenyl cyclase, like NaK-ATPase, seems not to be a normal constituent of brush borders. Both these enzymes are present in plasma membrane preparations derived largely from the basal and lateral margins of the epithelial cells, both may be phospholipid dependent enzymes and both are affected by cholera toxin. Adenyl cyclase activity is increased while NaK-ATPase is decreased. The activities of alkaline phosphatase, leucineaminopeptidase, 5'-nucleotidase, glucose-6-phosphatase, and Mg-ATPase were not found to be affected by the toxin. Cholera toxin, which makes contact with the luminal side of the epithelial cells, in the natural disease and in the experimental model, would appear to exert its pathologic effect on adenyl cyclase at the opposite (basal and lateral) side of the cells.
\end{abstract}

\section{INTRODUCTION}

The small intestine of the rabbit is a useful model for the study of the action of cholera toxin $(1,2)$. Application of the enterotoxin to the lumen of the intestine results, after a brief latent period, in accumulation of fluid. This occurs in the duodenum, jejunum, and ileum so that the whole of the small intestine can be involved (3-5). It has been shown that the toxin effect is mediated by a

Dr. Parkinson's present address is Hospital for Sick Children, Toronto 101, Ontario, Canada.

Dr. Ebel's present address is Institute of Clinical Physiology, Klinikum Steglitz, Free University of Berlin, Germany.

Received for publication 2 March 1972 and in revised form 17 April 1972. stimulation of the enzyme adenyl cyclase and increased intracellular concentrations of adenosine $3^{\prime}, 5^{\prime}$-cyclic monophosphate (cyclic AMP) ${ }^{1}(6-12)$. The cyclic AMP causes fluid accumulation by its subsequent effects upon electrolyte transport (13-15).

One striking feature of the action of toxin is its effectiveness after only brief contact with the intestine (16). Exposure for only $5 \mathrm{~min}$ is followed by a gradual increase in both adenyl cyclase activity and fluid accumulation over the next several hours." Thus a rapid interaction with the tissue results in progressive and irreversible changes. This would appear to be an unusual result. The toxin is a protein macromolecule with a molecular weight of around $84,000(17,18)$ which would not be expected to enter the epithelial cells rapidly. Thus the following studies were performed in an attempt to localize the site of action of cholera toxin on adenyl cyclase in the intestinal cells. In addition, the activities of several other enzymes were measured to assess the homogeneity of purified cell membrane fractions and to determine if cholera toxin affects more than the one enzyme.

\section{METHODS}

Preparation of membranes. New Zealand white rabbits were used for the study. They were anesthetized with i.v. sodium pentobarbital, the abdomen opened and a portion of the ileum cleaned by washing the succus entericus into a more distal portion of the intestine with Ringer's solution. Two loops of intestine were prepared for use in each animal separated by a third small loop. Double sutures were used to seal off each loop and rubber catheters were inserted to drain them. Care was taken that the blood supply was not affected by the sutures. $100 \mathrm{mg}$ of cholera toxin (essentially a dried crude culture filtrate, Wyeth-NIH lot 001) was placed in

\footnotetext{
${ }^{1}$ Abbreviations used in this paper: cyclic AMP, adenosine $3^{\prime}, 5^{\prime}$-cyclic monophosphate; IMP, inosine-5'-monophosphate; TCA, trichloracetic acid.

Sharp, G. W. G., and S. Hynie. Unpublished data.
} 
one loop in each animal; the drain tubes were closed, and opened after $60 \mathrm{~min}$ to allow drainage of fluid. The abdomen was closed after toxin administration until the end of a $3 \mathrm{hr}$ incubation period. The loops of intestine were then cut out, rinsed in ice-cold Ringer's solution, and membranes purified by a combination of the methods of Forstner, Sabesin, and Isselbacher (19) and Quigley and Gotterer (20). The cells were scraped off with a glass slide, weighed, and placed in a Waring blender with $75 \mathrm{vol}$ of ice-cold $5 \mathrm{~mm}$ EDTA at $\mathrm{pH}$ 7.5. The cells were then homogenized for $20 \mathrm{sec}$ and centrifuged at $450 \mathrm{~g}$ for $10 \mathrm{~min}$. The supernatant was set aside for later purification of basal and lateral membranes. The sediment was washed three times in 5 vol of EDTA buffer, sedimenting at $450 \mathrm{~g}$ between each wash. The third such sediment was used as the crude brush border preparation. This fraction was purified further by mixing with 2 vol of $90 \mathrm{~mm} \mathrm{NaCl}$ + $0.8 \mathrm{~mm}$ EDTA, allowing to stand for $30 \mathrm{~min}$ or until a sediment developed, and then pouring through glass wool and No. 25 bolting silk. The filter was washed with $20 \mathrm{ml}$ of $5 \mathrm{~mm}$ EDTA buffer, and the total washings were sedimented by centrifugation at $450 \mathrm{~g}$ for $10 \mathrm{~min}$. One further wash was performed with 2.5 vol of $2.5 \mathrm{~mm}$ EDTA buffer to give the final purified brush border preparation.

The supernatant, previously set aside for plasma membrane preparation, was centrifuged at $10,000 \mathrm{~g}$ for $10 \mathrm{~min}$ and the

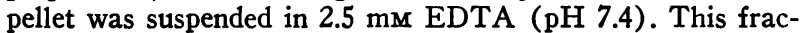
tion was then "aged" by a $3 \mathrm{hr}$ incubation at $37^{\circ} \mathrm{C}$. Then it was layered over a gradient composed of $20 \%, 30 \%$, and $40 \%$ sucrose (densities equal to $1.08,1.13$, and 1.18 , respectively) and centrifuged in an SW 25.3 rotor at 19,000 $\mathrm{rpm}$ for $90 \mathrm{~min}$ at $4^{\circ} \mathrm{C}$. The fraction placed on sucrose for centrifugation is referred to as the F II fraction by Quigley and Gotterer (20), the membrane fraction between $20 \%$ and $30 \%$ sucrose as the $M_{1}$ band (density interface, $d=1.08 / 1.13$ ), the membrane fraction between the $30 \%$ and $40 \%$ sucrose (density interface, $\mathrm{d}=1.13 / 1.18$ ) as $\mathrm{M}_{2}$. We have retained these designations in this paper. The bands were removed and sedimented in $1 \mathrm{~mm}$ Tris buffer ( $\mathrm{pH} 7.5)$ by centrifuging at $14,000 \mathrm{~g}$ for $30 \mathrm{~min}$. All the preparations were suspended in Tris buffer for enzyme assay.

Microscopy. Brush border isolation was monitored at several stages by phase microscopy. Purified fractions were fixed in phosphate buffered $3 \%$ glutaraldehyde and prepared in a conventional way for electron microscopy by thin sectioning techniques. The remaining membrane fractions were assayed by negative staining with ammonium molybdate. All examination was performed on a Philips EM-200 electron microscope.

Adenyl cyclase. Adenyl cyclase activity was determined by the method of Krishna, Weiss, and Brodie (21). Samples of the epithelial cell membrane preparations of small intestinal mucosa $(20-60 \mu \mathrm{g}$ of protein in $20 \mu \mathrm{l}$ Tris-Mg buffer) were added to $30 \mu \mathrm{l}$ of incubation mixture containing $1 \mu \mathrm{Ci}$-ATP$\alpha^{32} \mathrm{P}$ and incubated at $37^{\circ} \mathrm{C}$ for $20 \mathrm{~min}$. The final composition of the incubation mixture was: Tris- $\mathrm{HCl}$ buffer, $30 \mathrm{~mm}$; (pH 7.5) ; cyclic AMP, $0.1 \mathrm{mM}$; ATP, $0.1 \mathrm{~mm} ; \mathrm{MgCl}_{2}, 5$ $\mathrm{mM}$; phosphoenolpyruvate, $5 \mathrm{mM}$; phosphoenolpyruvate kinase, $40 \mu \mathrm{g} / \mathrm{ml}$, and myokinase $20 \mu \mathrm{g} / \mathrm{ml}$. Reaction blanks for each set of experiments were estimated in the absence of homogenate.

To terminate the reaction, $1 \mathrm{ml}$ of a solution containing 50 $\mu \mathrm{g}$ of cyclic AMP, $100 \mu \mathrm{g}$ ATP, and cyclic $\mathrm{AMP}-{ }^{8} \mathrm{H}$ for calculation of recovery was added to each reaction mixture. The reaction tubes were then immersed in boiling water for $5 \mathrm{~min}$. The contents of the tubes were transferred to $0.6 \times$ $4.0 \mathrm{~cm}$ chromatographic columns of AG $50 \mathrm{~W}-\mathrm{X} 2(200-400$ mesh) resin. The cyclic AMP was eluted by water in the 4th and fifth $\mathrm{ml}$. Impurities in this fraction were removed by two precipitations with $0.25 \mathrm{M} \mathrm{ZnSO}$, and $0.25 \mathrm{M} \mathrm{Ba}(\mathrm{OH})_{2}$, care being taken that the final $\mathrm{pH}$ of the solution was close to 7.5. After centrifugation for $10 \mathrm{~min}$ at $2000 \mathrm{~g}$ the precipitation was repeated. Then the supernatant was transferred to scintillation vials and ${ }^{3} \mathrm{H}$ and ${ }^{32} \mathrm{P}$ estimated by double isotope counting in a liquid scintillation counter. Recovery of cyclic AMP as estimated with cyclic $\mathrm{AMP}-{ }^{3} \mathrm{H}$ was $50-70 \%$. The amount of cyclic AMP formed was calculated from the specific activity of $A T P{ }^{22} P$ in the incubation mixture and the amount of cyclic AMP- ${ }^{22} \mathrm{P}$ recovered minus the reaction blank.

Adenosinetriphosphate-phosphohydrolase. ATPase (E.C.3.6.1.3) activity was determined by the amount of inorganic phosphate produced during the incubation of subcellular fractions with ATP. MgNaK-ATPase was determined in a medium consisting of $\mathrm{MgCl}_{2}, 3 \mathrm{~mm}$; Tris-ATP, $3 \mathrm{~mm} ; \mathrm{NaCl}$, $100 \mathrm{~mm} ; \mathrm{KCl}, 20 \mathrm{~mm}$, and imidazole- $\mathrm{HCl}, 70 \mathrm{~mm} ; \mathrm{pH}, 7.5$. $\mathrm{Mg}$-ATPase was measured by omitting $\mathrm{NaCl}$ and $\mathrm{KCl}$. After $30 \mathrm{~min}$ at $37^{\circ} \mathrm{C}$ the reaction was stopped by the addition of ice-cold trichloracetic acid (TCA). Inorganic phosphate was determined in the supernatant by the method of Fiske and Subbarow (22). Protein was determined by the method of Lowry, Rosenbrough, Farr, and Randall (23) using crystalline bovine albumin as the standard. The specific activity of ATPase and other phosphatases was expressed as $\mu$ moles phosphate $\cdot$ milligram protein ${ }^{-1} \cdot \mathrm{hr}^{-1}$. $\mathrm{NaK}$-ATPase was defined as the difference in the specific activities of $\mathrm{MgNaK}$ ATPase and MgATPase.

5'-Nucleotidase. 5'-Nucleotidase (E.C.3.1.3.5.) was determined with inosine- $5^{\prime}$-monophosphate (IMP) as substrate in a medium of $\mathrm{MgCl}_{2}, 5 \mathrm{mM}$; IMP, $5 \mathrm{mM} ; \mathrm{CoCl}_{2}, 1 \mathrm{mM}$; and maleinic acid-Tris buffer, $50 \mathrm{~mm} ; \mathrm{pH}, 6.5$.

Glucose-6-phosphatase. Glucose-6-phosphatase (E.C.3.1.3.9) was measured by the method of Huebscher and West (24) with glucose-6-phosphate, $10 \mathrm{~mm}$, in a $50 \mathrm{~mm}$ maleinic acid- $\mathrm{NaOH}$ buffer at $\mathrm{pH}$ 6.0. The reaction medium included $\mathrm{Na}_{2}$ EDTA, $4 \mathrm{~mm}$; and $\mathrm{NaF}, 1 \mathrm{~mm}$, to inhibit alkaline phosphatase and acid phosphatase activity. In both enzyme assays the amount of $\mathrm{Pi}$ liberated in a $30 \mathrm{~min}$ incubation period at $37^{\circ} \mathrm{C}$ was determined in the supernatant after stopping the reaction with TCA.

Alkaline phosphatase. Alkaline phosphatase (E.C.3.1.4.1) was determined with $5 \mathrm{mM} p$-nitrophenylphosphate as the substrate, $\mathrm{MgCl}_{2}, 20 \mathrm{mM} ; \mathrm{ZnCl}_{2}, 0.5 \mathrm{mM}$ as activator in 50 mM glycine- $\mathrm{NaOH}$ buffer; $\mathrm{pH}, 9.5$. The reaction was stopped after $15 \mathrm{~min}$ by the addition of TCA. After centrifugation the supernatant was neutralized with Tris, diluted with distilled water, and the amount of liberated $p$-nitrophenol measured at $400 \mathrm{~nm}$. Enzyme activity was expressed in $\mu$ mole $p$-nitrophenol $\cdot$ milligram $\operatorname{protein}^{-1} \cdot \mathrm{hr}^{-1}$.

Leucineaminopeptidase. Leucineaminopeptidase (E.C.3.4. 1.1) was measured according to the method of Tuppy, Wiesbauer, and Wintersberger (25). The reaction medium consisted of $10 \mathrm{~mm}$ leucine-p-nitroanaline as substrate in $\mathrm{MgCl}_{2}$, $1 \mathrm{~mm}$; and Tris buffer, $50 \mathrm{~mm}$ at $\mathrm{pH}, 7.6$. The amount of $p$-nitroaniline liberated at $25^{\circ} \mathrm{C}$ was recorded at $405 \mathrm{~nm}$ with a Beckman-Gilford recorder over a time period of $5 \mathrm{~min}$. Enzyme activity was expressed in $\mu$ mole $p$-nitroaniline. milligram protein ${ }^{-1} \cdot \mathrm{min}^{-1}$.

Succinodehydrogenase. Succinodehydrogenase (E.C.1.3.99.1) was measured by recording the succinate dependent reduction if dichloroindophenol to leucoindophenol at $578 \mathrm{~nm}$ according to the method reported by Green, Mii, and Kolout (26). The assay medium contained potassium-phosphate buf- 
TABLE I

Enzyme Activities of Brush Border Preparations from Rabbit Ileum under Control Conditions and after Treatment with Cholera Toxin

\begin{tabular}{|c|c|c|c|}
\hline \multirow[b]{2}{*}{ Enzyme } & \multicolumn{2}{|c|}{ Brush borders } & \multirow[b]{2}{*}{ No. } \\
\hline & Control & Toxin & \\
\hline & \multicolumn{2}{|c|}{ umole $\cdot m g$ protein ${ }^{-1} \cdot h r^{-1} \pm \mathrm{SEM}$} & \\
\hline Alkaline phosphatase & $129.5 \pm 20.7$ & $131.5 \pm 21.0$ & 15 \\
\hline Leucineaminopeptidase* & $26.4 \pm 5.4$ & $21.8 \pm 5.6$ & 15 \\
\hline $5^{\prime}$-Nucleotidase & $3.3 \pm 0.6$ & $3.8 \pm 0.6$ & 13 \\
\hline Glucose-6-phosphatase & $1.9 \pm 0.3$ & $2.2 \pm 0.6$ & 13 \\
\hline Mg-ATPase & $11.5 \pm 2.7$ & $11.3 \pm 1.9$ & 9 \\
\hline NaK-ATPase & $2.1 \pm 0.6$ & $1.5 \pm 0.6$ & 9 \\
\hline
\end{tabular}

* nmole $\cdot \mathrm{mg}$ protein ${ }^{-1} \cdot \mathrm{min}^{-1} \pm \mathrm{SEM}$.

fer, $10 \mathrm{~mm}$, at $\mathrm{pH}, 7.5$; albumin, $500 \mu \mathrm{g} / \mathrm{ml}$; potassium cyanide, $1 \mathrm{mM}$; 2,6-dichloroindophenol, $25 \mu \mathrm{g} / \mathrm{ml}$; and sodium succinate, $10 \mathrm{~mm}$. The extinction coefficient was take to be $14.3 \times 10^{8} \mathrm{~cm}^{2} \mathrm{~mole}^{-1}(27)$.

\section{RESULTS}

\section{Purification of brush borders}

The brush borders were characterized by a high amount of alkaline phosphatase activity (see Table I)
TABLE II

Enzyme Activities of Purified Plasma Membrane Preparations from Rabbit Ileum under Control Conditions and after Treatment with Cholera Toxin

\begin{tabular}{|c|c|c|c|}
\hline \multirow[b]{2}{*}{ Enzyme } & \multicolumn{2}{|c|}{ Plasma membranes } & \multirow[b]{2}{*}{ No } \\
\hline & Control & Toxin & \\
\hline & \multicolumn{2}{|c|}{ umole $\cdot m g$ protein ${ }^{-1} \cdot h r^{-1} \pm \mathrm{SE}$} & \\
\hline Alkaline phosphatase & $9.9 \pm 1.5$ & $10.9 \pm 1.9$ & 14 \\
\hline Leucineaminopeptidase* & $13.9 \pm 1.8$ & $10.1 \pm 1.8$ & 15 \\
\hline 5'-Nucleotidase & $3.4 \pm 1.1$ & $2.1 \pm 0.4$ & 11 \\
\hline Glucose-6-phosphatase & $2.4 \pm 0.4$ & $2.7 \pm 0.4$ & 14 \\
\hline Mg-ATPase & $13.4 \pm 3.0$ & $16.8 \pm 3.5$ & 11 \\
\hline NaK-ATPase & $13.1 \pm 4.0$ & $5.4 \pm 4.5$ & 11 \\
\hline
\end{tabular}

${ }^{*}$ nmole $\cdot \mathrm{mg}$ protein ${ }^{-1} \cdot \min ^{-1} \pm \mathrm{SE}$.

and also by leucine amino peptidase activity. At the same time moderate activities of ATPase, $85 \%$ of which was Mg-ATPase, 5'-nucleotidase and glucose-6-phosphatase were measured. In all enzyme activities listed in Table I there was no significant difference between brush borders derived from control or cholera toxin-treated loops. The successful isolation of purified brush borders is indicated by the high alkaline phosphatase activity and appearance

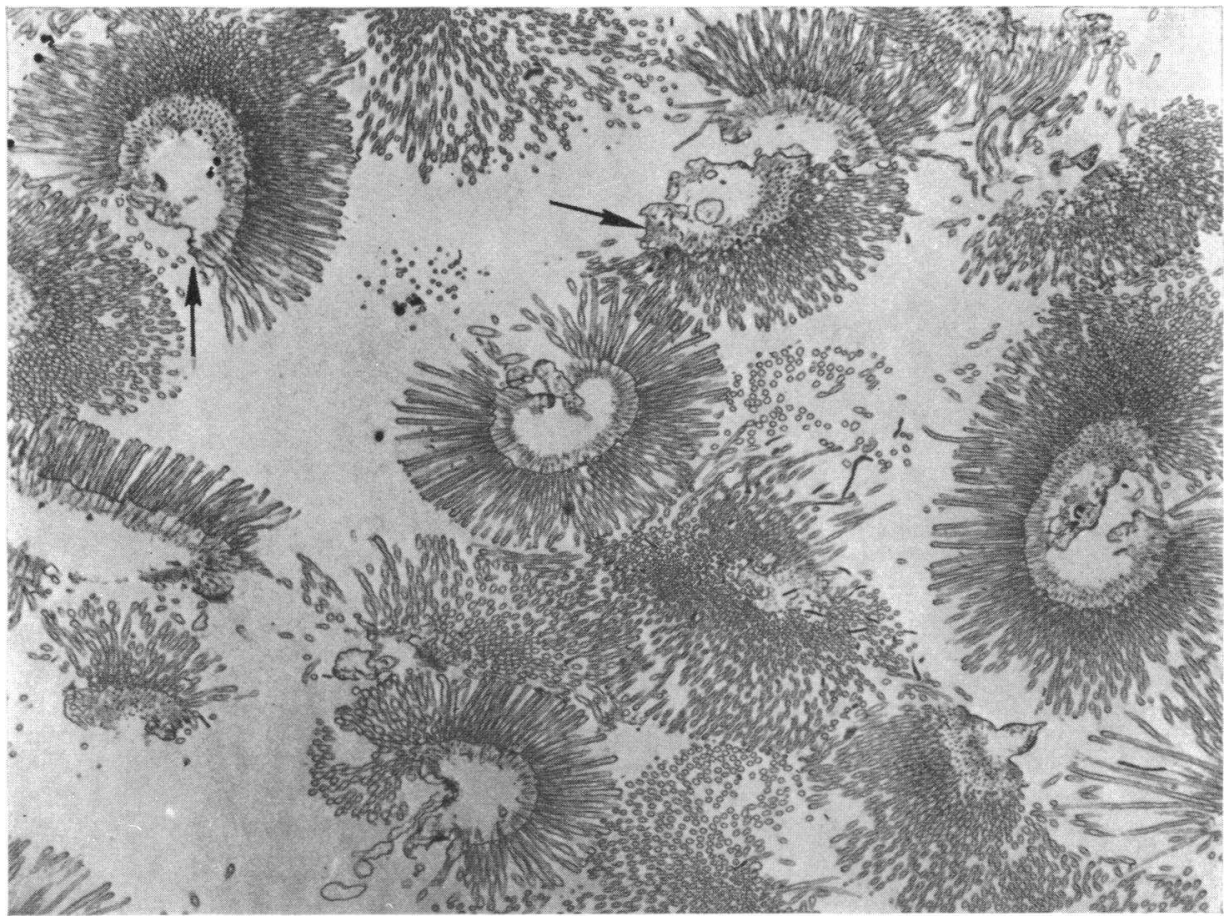

FIGURE 1 Electron micrograph of sample brush border preparation. These elements appear to be intact. Tags of lateral cell membrane are evident (arrows) and appear to be the only nonbrush border constituents in the preparation. $\times 7500$. 
under phase and electron microscopic examination (Fig. $1)$.

\section{Purification of outer cell membranes}

As can be seen in Table II the purified cell membrane fraction (equivalent to the $M_{1}$ band of Quigley and Gotterer [20]) exhibited low levels of alkaline phosphatase activity. Moderate leucineaminopeptidase activity was also present. Electron microscopy showed that large amounts of membrane material, relatively free of mitochondria and brush borders was present (Fig. 2). For the enzymes listed in Table II no difference in activity was observed except for NaK-ATPase. This enzyme however had its activity reduced $60 \%$ by the action of cholera toxin.

\section{Studies with adenyl cyclase}

Localization and the effect of cholera toxin. In Table III is shown the specific activity of adenyl cyclase in the supernatant obtained by homogenization in the Waring blender and centrifugation at $450 \mathrm{~g}$, and in the brush borders. In both supernatant and brush border fractions adenyl cyclase activity was increased by cholera toxin. The specific activity in the supernatant was four times greater than that in the brush border for control tissue
TABLE III

Adenyl Cyclase Activity in "Supernatant" and Brush Border Preparations from Rabbit Ileum under Control Conditions and after Treatment with Cholera Toxin

\begin{tabular}{|c|c|c|c|}
\hline & \multicolumn{2}{|c|}{ Adenyl cyclase activity } & \multirow[b]{2}{*}{ No. } \\
\hline & Supernatant & Brush border & \\
\hline & \multicolumn{2}{|c|}{$\begin{array}{c}\text { pmoles cyclic AMP } \cdot \mathrm{mg} \text { protein }-1 \\
\cdot 20 \mathrm{~min}^{-1} \pm \mathrm{SE}\end{array}$} & \\
\hline Control & $85.0 \pm 15.6$ & $20.8 \pm 1.9$ & 7 \\
\hline Toxin & $317.9 \pm 74.2$ & $38.9 \pm 4.9$ & 7 \\
\hline
\end{tabular}

and eight times greater for the toxin-treated tissue. The reason for these discrepant ratios between control and toxin-treated tissue is not known. The essential point is that the supernatant has a much higher specific activity than the brush border. As the amount of material in the supernatant is greater than that of the brush border, the absolute amounts of adenyl cyclase in each fraction show that a preponderance of the enzyme is in the supernatant. This can be seen from the results in Table IV where the cyclase is expressed in absolute terms (i.e. the total amount of cyclic AMP produced by each fraction). Total brush border activity is only $5 \%$ or less of the total

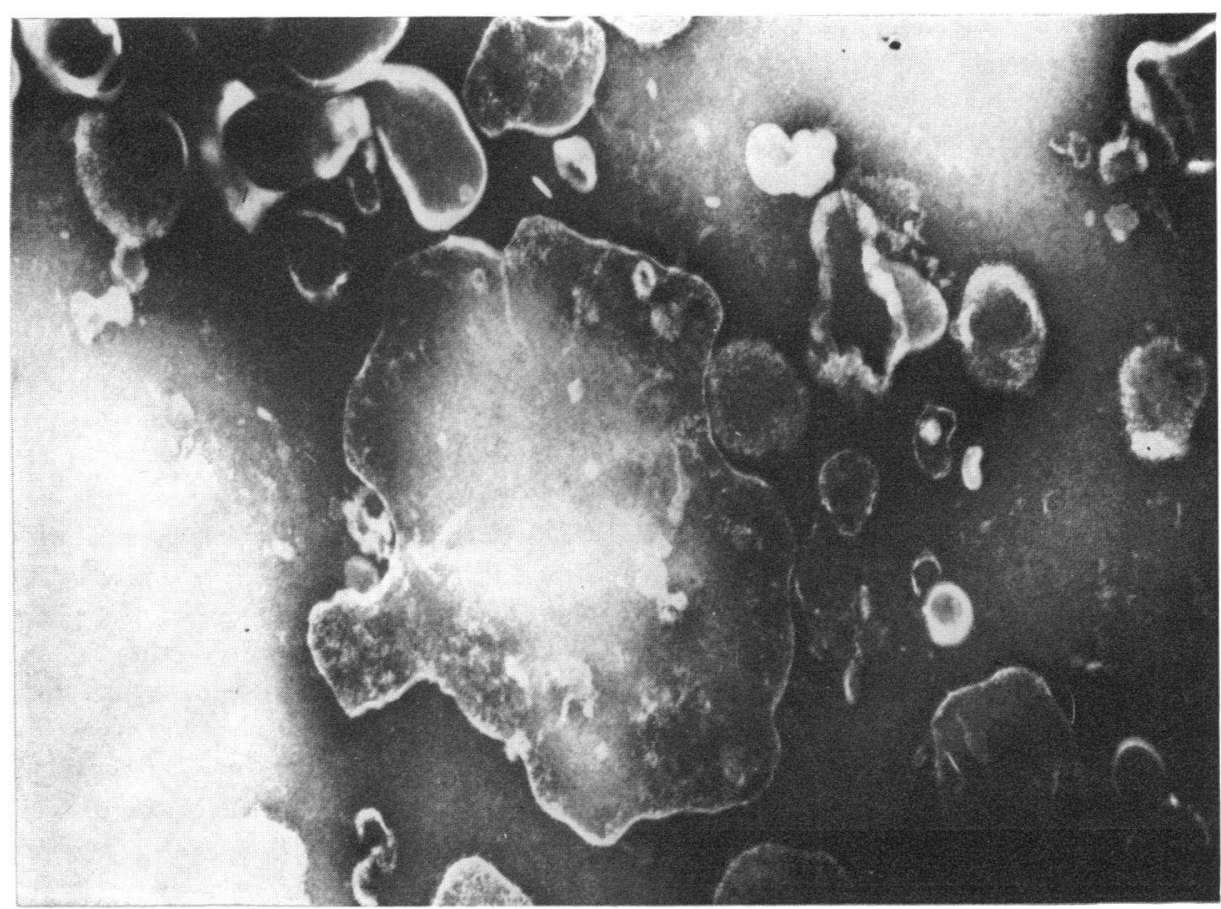

FIGURE 2 Negatively stained preparation of $\mathrm{M}_{1}$ band material. This preparation consists of large smooth-surfaced elements identified as plasma membrane fragments. This fraction was relatively free of mitochondria and microsomes which were found in the $M_{2}$ band (not shown). Preparation negatively stained with ammonium molybdate. $\times 50,000$. 
TABLE IV

Adenyl Cyclase Activity in "Supernatant" and Brush Border

Preparations from Rabbit Ileum under Control Conditions and after Treatment with Cholera Toxin

\begin{tabular}{lccc}
\hline & Supernatant & Brush border & No. \\
\hline Control & $1.2 \pm 0.1$ & $0.06 \pm 0.01$ & 7 \\
Toxin & $3.5 \pm 0.7$ & $0.14 \pm 0.02$ & 7
\end{tabular}

Adenyl cyclase activity expressed as $\mu$ moles cyclic AMP produced in $20 \mathrm{~min}$ (total activity) $\pm \mathrm{SE}$.

activity. It is concluded, therefore, that adenyl cyclase is present in only small amounts in brush borders, and may be present only as a contaminant introduced during homogenization.

After purification of the supernatant by centrifugation at $10,000 \mathrm{~g}$, resuspension in buffer, "aging" and centrifugation over a discontinuous sucrose gradient, three fractions were tested for adenyl cyclase activity. These were the fraction put on the gradient and the membranes found in the $M_{1}$ and $M_{2}$ bands. The results are shown in Table V. The highest specific activity was found in the $\mathrm{M}_{1}$ band-the purified plasma membrane preparation of Quigley and Gotterer.

\section{DISCUSSION}

In histochemical studies of the intestinal epithelium, alkaline phosphatase has been located in the brush borders but not at the basal or lateral membranes (Brandes, Zettergvist, and Sheldon [28] ; Clark [29]). In the present work the brush borders were characterized by the presence of a highly active alkaline phosphatase. A comparable amount of alkaline phosphatase activity was reported by Quigley and Gotterer (20) for a brush border preparation from the rat intestine. Even higher alkaline phosphatase activities were reported by Forstner et al. (19) and by Eichholz and Crane (30) in brush border preparations of the rat and hamster intestine. The high activity of alkaline phosphatase in this fraction indicates a successful isolation of the brush borders from

\section{TABLE V}

'Adenyl Cyclase Activity in the F II, $M_{1}$, and $M_{2}$ Fractions of Mucosal Cells of Rabbit Ileum under Control Conditions and after Treatment with Cholera Toxin

\begin{tabular}{|c|c|c|c|c|}
\hline & \multicolumn{3}{|c|}{ Membrane fraction } & \multirow[b]{2}{*}{ No. } \\
\hline & F II & $\mathbf{M}_{1}$ & $\mathbf{M}_{2}$ & \\
\hline \multicolumn{5}{|c|}{ pmoles cyclic $A M P \cdot m g$ protein $-1 \cdot 20 \mathrm{~min}^{-1} \pm \mathrm{SE}$} \\
\hline Control & $21.2 \pm 4.1$ & $43.2 \pm 11.0$ & $12.0 \pm 3.1$ & 9 \\
\hline Toxin & $69.1 \pm 13.5$ & $112.6 \pm 23.3$ & $44.2 \pm 10.2$ & 9 \\
\hline
\end{tabular}

the rabbit intestine. This conclusion is supported by the electron microscopic appearance of the fraction. However, it is evident that there are other enzyme activities present that are not typical for brush borders. First, the low but measurable activities of NaK-ATPase indicated a contamination of the fraction with plasma membranes. This contamination might be due to adherent tags from the lateral membranes which can be seen by electron microscopy (see Fig. 1). The percentage contamination with plasma membranes, however, is low. If one takes the NaK-ATPase as a marker enzyme for plasma membranes and presumes that the measured specific activities of different subcellular fractions are quantitatively comparable, then the contamination is not greater than $15 \%$. Contamination of the brush border preparation with subcellular fractions was the same in the control and cholera toxin-treated loops.

The purity of the plasma membrane fraction, which was collected at the density interface of $d=1.08 / 1.13$ was checked similarly by measurement of marker enzyme activity and by electron microscopy. The presence of NaK-ATPase in plasma membranes of the intestinal epithelial cells has been shown by Quigley and Gotterer (20). In the present study the highest NaK-ATPase activity was found after sucrose density centrifugation of the $10,000 \mathrm{~g}$ sediment at the density interface, $\mathrm{d}=1.08$ / 1.13. The pattern of other enzyme activities present in this fraction indicated that some membranes derived from the brush borders, from mitochondria and endoplasmic reticulum are present in this fraction. However, the activity of these other "marker enzymes" was considerably lower than in their fraction of origin. The alkaline phosphatase activity was only $7 \%$ related to the enzyme activity in the brush borders, the succinodehydrogenase activity was only $12 \%$ of the mitochondrial activity in membranes collected at the density interface, $d=$ $1.13 / 1.18$. Also, the glucose-6-phosphatase activity was approximately $50 \%$ lower than in a crude microsomal fraction. The presence of glucose-6-phosphatase activity in the plasma membranes is difficult to interpret because it is known from a recent report of Emmelot and Bos (31) that the glucose-6-phosphatase of the plasma membrane fraction from rat liver showed different properties than that derived from the endoplasmic reticulum. Thus, this enzyme might be present also as a constituent of the plasma membrane. From the evidence presented in the electron microscopic appearance as well as from the low contamination by other "marker enzymes" it can be concluded that the membranes of the density, $d=1.08 / 1.13$, represent a part of the plasma membranes. The contamination of plasma membranes by other subcellular fractions was similar in both the control and cholera toxin-treated loops.

After the treatment with cholera toxin there was no 
significant change in the activity of enzymes originating in the brush border. In the plasma membranes, however, the specific activities of adenyl cyclase increased threefold while that of NaK-ATPase decreased to $40 \%$ of the control value.

An inhibition of mucosal NaK-ATPase in cholera patients who had undergone intestinal biopsy was reported earlier by Hirschhorn and Rosenberg (32). The same enzyme inhibition was found in experiments in which a microsomal preparation of the intestinal mucosa was incubated in vitro with unpurified Vibrio cholerae culture filtrates (Richardson [33]). In the present work it has been demonstrated that it is the NaK-ATPase in the plasma membranes that is inhibited after the in vivo application of cholera toxin to the intestine of rabbits.

There are three main conclusions from this work: $(a)$ Adenyl cyclase, like NaK-ATPase seems not to be present in the brush borders of intestinal epithelial cells. This point has been made previously by Hollingsworth (34) who studied the activities of several enzymes in the chick small intestine. He found no adenyl cyclase activity in the brush borders.

(b) It follows from the first conclusion that cholera toxin, which is present at the luminal surface of the intestinal epithelial cells during naturally acquired cholera and experimentally, cannot affect adenyl cyclase in the brush border with which it is in contact, but in these cells must affect the enzyme in the lateral and basal plasma cell membranes. This is of importance to our understanding of the detailed mechanism of the action of the toxin. It follows that the toxin either affects the brush borders to trigger changes subsequently affecting the lateral and basal plasma cell membranes, or that the brush borders are involved in the rapid binding and uptake of cholera toxin and that it subsequently migrates to the site of its action. One reservation to this conclusion would apply if cholera toxin affected only the crypt cells which do not have a brush border, the luminal membrane of which is presumably present in the $M_{1}$ fraction. While not eliminating this possibility it should be pointed out that (1) all cell types that have been exposed to cholera toxin thus far have responded with an increase in adenyl cyclase activity. Thus, those cells in the intestine which do not have brush borders would presumably be affected by cholera toxin, and (2) that the crypt cells make up only a small proportion of the intestinal cells.

Changes in transport and permeability which are mediated by cyclic AMP after stimulation of adenyl cyclase by the toxin, may occur at one or more loci on brush border, basal, and lateral membranes.

(c) Cholera toxin does not specifically affect adenyl cyclase. It has in addition an effect upon NaK-ATPase. As evidence is available that both these membrane bound enzymes are phospholipid dependent the toxin could act via an effect on the membrane phospholipids. Investigations are continuing into a possible effect of cholera toxin on membrane lipids.

\section{ACKNOWLEDGMENTS}

The authors are grateful to Patricia Witkum and Bonnie Lord for their skilled assistance. The investigation was supported by a grant from the John A. Hartford Foundation, Inc., and by the U. S. Public Health Service grants HL06664 from the National Heart Institute and AM 04501 from the National Institute of Arthritis and Metabolic Diseases. G. W. G. Sharp was supported by a Public Health Service Research Career Development Award of the National Institute of Arthritis and Metabolic Diseases, 1 K04 AM42376.

\section{REFERENCES}

1. De, S. N., and D. N. Chatterje. 1953. An experimental study of the mechanism of action of Vibrio cholerae on the intestinal mucous membrane. J. Pathol. Bacteriol. 66: 559 .

2. Dutta, N. K., and M. K. Habbu. 1955. Experimental cholera in infant rabbits: a method for chemotherapeutic investigation. Brit. J. Pharmacol. 10: 153.

3. Sack, R. B., C. C. J. Carpenter, R. W. Steenberg, and N. F. Pierce. 1966. Experimental cholera: a canine model. Lancet. 2 : 206.

4. Carpenter, C. C. J., R. B. Sack, J. C. Feeley, and R. W. Steenberg. 1960. Site and characteristics of electrolyte loss and effect of intraluminal glucose in experimental canine cholera. J. Clin. Invest. 47: 1210.

5. Banwell, J. G., N. F. Pierce, R. C. Mitra, K. L. Brigham, G. J. Caranasos, R. I. Keimowitz, D S. Fedson, J. Thomas, G. L. Gorbach, R. B. Sack, and A. Mondal. 1970. Intestinal fluid and electrolyte transport in human cholera. J. Clin. Invest. 49: 183.

6. Schafer, D. E., W. D. Lust, B. Sircar, and N. D. Goldberg. 1970. Elevated concentration of adenosine-3',5'cyclic monophosphate in intestinal mucosa after treatment with cholera toxin. Proc. Natl. Acad. Sci. U. S. A. $67: 851$.

7. Sharp, G. W. G., and S. Hynie. 1971. Stimulation of intestinal adenyl cyclase by cholera toxin. Nature (Lond.). 229: 266.

8. Kimberg, D. V., M. Field, J. Johnson, A. Henderson, and I. Gershon. 1971. Stimulation of intestinal mucosal adenyl cyclase by cholera enterotoxin and prostaglandins. J. Clin. Invest. 50: 1218.

9. Sharp, G. W. G., S. Hynie, L. C. Lipson, and D. Parkinson. 1971. Action of cholera toxin to stimulate adenyl cyclase. Trans. Assoc. Am. Phys. 84: 200.

10. Chen, L. C., J. E. Rohde, and G. W. G. Sharp. 1971. Intestinal adenyl cyclase activity in human cholera. Lancet. 1 : 939.

11. Chen, L. C., J. E. Rohde, and G. W. G. Sharp. 1972. Properties of adenyl cyclase from human jejunal mucosa during naturally acquired cholera and convalescence. J. Clin. Invest. $51: 731$.

12. Guerrant, R. L., L. C. Chen, and G. W. G. Sharp. 1972. Correlation of intestinal adenyl cyclase activity and luminal fluid accumulation in canine cholera. J. Infect. Dis. 125 : 377. 
13. Field, M., G. R. Plotkin, and W. Silen. 1968. Effects of vasopressin, theophylline and cyclic adenosine monophosphate on short circuit current across isolated rabbit ileal mucosa. Nature (Lond.). 217: 469.

14. Pierce, N. F., C. C. J. Carpenter, H. L. Elliott, and W. B. Greenough III. 1971. Effects of prostaglandins, theophylline and cholera exotoxin upon transmucosal water and electrolyte movement in the canine jejunum. Gastroenterology. 60: 22.

15. Field, M. 1971. Ion transport in rabbit ileal mucosa. II. Effects of cyclic 3',5'-AMP. Am. J. Physiol. 221: 992.

16. Pierce, N. F., W. B. Greenough III, and C. C. J. Carpenter, Jr. 1971. Vibrio cholerae enterotoxin and its mode of action. Bacteriol. Rev. 35: 1.

17. Finkelstein, R. A., and J. J. LoSpalluto. 1969. Pathogenesis of experimental cholera: preparation and isolation of choleragen and choleragenoid. J. Exp. Med. 130: 185 .

18. LoSpalluto; J. J., and R. A. Finkelstein. 1972. Chemical and physical properties of cholera exoenterotoxin (choleragen) and its spontaneously formed toxoid (choleragenoid). Biochim. Biophys. Acta. $257: 158$.

19. Forstner, G. G., K. J. Sabesin, and K. J. Isselbacher. 1968. Rat intestinal microvillus membranes. Purification and biochemical characterization. Biochem. J. 106: 381.

20. Quigley, J. P., and G. S. Gotterer. 1969. Distribution of $\left(\mathrm{Na}^{+}+\mathrm{K}^{+}\right)$stimulated ATPase activity in rat intestinal mucosa. Biochim. Biophys. Acta. 173: 456.

21. Krishna, G. B., B. Weiss, and B. B. Brodie. 1968. A simple sensitive method for the assay of adenyl cyclase. J. Pharmacol. Exp. Ther. 163: 379.

22. Fiske, C. H., and Y. Subbarow. 1925. The colorimetric determination of phosphorus. J. Biol. Chem. 66: 375 .

23. Lowry, O. H., N. J. Rosenbrough, A. L. Farr, and R. J. Randall. 1951. Protein measurement with the Folin-phenol reagent. J. Biol. Chem. 193: 265.

24. Huebscher, G., and G. R. West. 1965. Specific assays of some phosphatases in subcellular fractions of small intestinal mucosa. Nature (Lond.). 205: 799.

25. Tuppy, H., U. Wiesbauer, and E. Wintersberger. 1962. Amino acid- $p$-nitroanilide as a substrate for aminopeptidases and other proteolytic enzymes. $Z$. Physiol. Chem. $329: 278$.

26. Green, D. E., S. Mii, and P. M. Kohout. 1955. Studies on the terminal electron transport system. I. Succinic dehydrogenase. J. Biol. Chem. 217: 551.

27. Seubert, W. In Methoden der enzymatischen Analyse. 1962. H. U. Bergmeyer, editor. Verlag-Chemie, Weinheim, Germany. 433.

28. Brandes, D., H. Zettergvist, and H. Sheldon. 1956. Histochemical techniques for electron microscopy: alkaline phosphatase. Nature (Lond.). 177: 382.

29. Clark, S. L. 1961. The localization of alkaline phosphatase in tissues of mice, using the electron microscope. Am. J. Anat. 109 : 57.

30. Eichholz, A., and R. K. Crane. 1965. Studies on the organization of the brush border in intestinal epithelial cells. I. Tris disruption of isolated hamster brush borders and density gradient separation of fractions. J. Cell. Biol. $26: 687$.

31. Emmelot, P., and C. J. Bos. 1966. Studies on plasma membranes. III. $\mathrm{Mg}^{2+}$-ATPase, $\left(\mathrm{Na}^{+}-\mathrm{K}^{+}-\mathrm{Mg}^{2+}\right)$-ATPase and $5^{\prime}$-nucleotidase activity of plasma membranes isolated from rat liver. Biochim. Biophys. Acta. 120: 369.

32. Hirschhorn, N., and I. M. Rosenberg. 1968. Sodiumpotassium stimulated adenosine triphosphatase of the small intestine of man: studies in cholera and other diarrhoeal disease. J. Lab. Clin. Med. 72: 28.

33. Richardson, S. H. 1968. An ion translocase system from rabbit intestinal mucosa. Preparation and properties of the $\left(\mathrm{Na}^{+}-\mathrm{K}^{+}\right)$-activated ATPase. Biochim. Biophys. Acta. 150: 572 .

34. Holdsworth, E. S. 1970. The effect of vitamin D on enzyme activities in the mucosal cells of the chick small intestine. J. Membrane Biol. 3 : 43. 